\title{
Extended Case Method (ECM) in Social and Cultural Research
}

\section{Extended Case Method (ECM) dalam Penelitian Sosial dan Budaya}

\author{
Firdaus $^{1 *}$, Nurus Shalihin ${ }^{2}$ \\ 1 STKIP PGRI Sumatera Barat. Indonesia. \\ 2 Universitas Islam Negeri (UIN) Imam Bonjol Padang, Indonesia. \\ *Correspondence author: firdaus.lasigo@gmail.com
}

\begin{tabular}{|c|c|}
\hline ARTICLE INFO & ABSTRACT \\
\hline $\begin{array}{l}\text { Keywords: } \\
\text { Extended Case Method; } \\
\text { Penelitian Sosial; } \\
\text { Etnografi; Studi Kasus. } \\
\text { How to cite: } \\
\text { Firdaus., Shalihin, N. } \\
\text { (2021). Extended Case } \\
\text { Method (ECM) dalam } \\
\text { Penelitian Sosial dan } \\
\text { Budaya. Etnosia: Jurnal } \\
\text { Etnografi Indonesia, 6(1), } \\
\text { 9-23. } \\
\text { DOI: } \\
\text { 10.31947/etnosia.v6i1.7147 }\end{array}$ & $\begin{array}{l}\text { This article aims to introduce the Extended Case Method (ECM) as an } \\
\text { approach to qualitative social research. As an approach, the ECM } \\
\text { rooted in the ethnography approach in the anthropological tradition } \\
\text { and developed in the sociological tradition research. With reference to } \\
\text { Michael Buroway as a developer of ECM and some articles that used } \\
\text { ECM as a method, this paper outlines the basic concepts of ECM, their } \\
\text { advantages and infirmity, and the application of theories in social } \\
\text { research by using ECM. As an extended case, there are four aspects } \\
\text { that extend on ECM, namely intervention, processes, structuration, } \\
\text { and reconstruction (theory). The advantage of ECM is their four } \\
\text { extending. Rather than the infirmity of ECM rooted from their } \\
\text { advantage, namely domination, silencing, objectification, and } \\
\text { normalization. The use of theory in ECM was carried out from the } \\
\text { beginning to the end of the study. Base on their characteristics, ECM } \\
\text { very feasible to use to understanding borderless society and ambiguity } \\
\text { of case study on research of social science in general, and ethnography } \\
\text { especially. }\end{array}$ \\
\hline
\end{tabular}

\section{Pendahuluan}

Irwan Abdullah (1999) dalam artikelnya yang berjudul "Dari Bounded System ke Borderless Society: Krisis Metode Antropologi dalam Memahami Masyarakat Masa Kini" yang dipublikasikan ulang oleh Jurnal Antropologi Indonesia pada tahun 2006, mengidentifikasi beberapa krisis metodologi antropologi dalam memahami masyarakat Indonesia kontemporer yang hidup dalam ruang geografis dan simbolis yang tanpa batas. Dengan bertumpu pada karya-karya Cliffort Geertz $(1973,1981,1992,1998)$ yang mengungkap dan menjelaskan masyarakat dan kebudayaan Indonesia, dan perubahan sosial yang dialaminya, Abdullah mengidentifikasi tiga tahap perubahan mendasar 
masyarakat Indonesia dalam berbagai aspek sejak kultur agraris mulai dipengaruhi oleh kekuatan luar. Pertama, perubahan pada ide komodifikasi hasil pertanian dan jaringan sosial masyarakat desa dengan orang luar desa karena masuknya pasar ke masyarakat petani. Kedua, terikatnya penduduk ke tatanan nilai, ide, dan praktik nasional karena integrasi pasar. Ketiga, perubahan orientasi warga desa ke orientasi global dengan nilai dan norma baru sebagai implikasi ekspansi pasar (Abdullah, 2006).

Pada setiap fase perubahan masyarakat agraris, yang terutama disebabkan oleh pengaruh pasar tersebut, telah terjadi pengaburan batas geografis dan simbolis masyarakat desa. Kaburnya batas tersebut secara berturut-turut mulai dari tingkat lokal (desa dan kecamatan), nasional (antara kabupaten dan propinsi) dan global (antar negara). Bentuk nyata dari kaburnya batasan tersebut dapat diidentifikasi pada perkawinan warga desa dengan orang luar desa, propinsi dan bahkan negara yang secara otomatis memiliki aspek sosial dan budaya yang berbeda. Implikasinya, metode ilmiah Antropologi menghadapi masalah karena ketiadaan batas ruang sosial dan budaya masyarakat agraris yang saling melampaui ruang geografis dan simbolis mereka masing-masing. Masalah metodologis utama yang dihadapi Antropologi adalah; pertama, analisis Antropologi terhadap pendefenisian dan pemaknaan kebudayaan sesuai dengan konteks dan simbol yang dibangun oleh kebudayaan tersebut. Kedua, tempat menemukan ruang kebudayaan yang sudah saling silang di berbagai ruang dan konteks yang berbeda. Ketiga, teknik pengumpulan data. Keempat, masalah representasi (siapa merepresentasikan apa), dan kelima, unit analisis (apakah mikro masih relevan?). Untuk mengatasi masalah-masalah tersebut, penelitian Antropologi menurut Irwan Abdullah perlu mempertimbangkan untuk melakukan perluasan metodologi. Perluasan tersebut dilakukan antara lain dengan meredefenisi "tempat" dimana kebudayaan dipelajari, mempertimbangkan ulang representasi, dan mengakomodir penggunaan berbagai teknologi sebagai alat dalam melakukan penelitian (Abdullah, 1999:191-192).

Selain krisis metode dalam Antropologi yang disebabkan oleh kaburnya batas geografis dan simbolis, keterbatasan juga terjadi pada metode studi kasus yang bertujuan untuk mempelajari dan mengetahui satu kasus tunggal. Keterbatasan studi kasus sebagai sebuah metode terletak pada kekuatan dan kedalaman analisis, dan generalisasi hasil penelitian (Creswell, 2010; Yin, 2003). Lebih dari itu, Verschuren (2003) juga mengidentifikasi tiga ambiguitas pada penelitian studi kasus. Pertama, pada aspek mengatasi keterbatasan kekuatan dan kedalaman analisis. Satu kelompok menyarankan pendekatan holistik dan kelompok lainnya menyarankan penggunaan multiple case. Kedua, batasan objek studi kasus yang masih belum clear antara fenomena yang akan dipelajari dan konteksnya. Dan ketiga, pada cara suatu objek studi kasus diamati, baik sebagai keseluruhan maupun sebagai konglomerasi (percampuran) dari berbagai bagian dan aspek. Mengatasi ambiguitas tersebut, selain menggunakan pendekatan holistik dan berfokus pada satu kasus, Verschuren (2003:124) berpandangan bahwa tidak ada alasan metodologis kenapa kejelasan batasan-batasan tersebut menjadi kriteria untuk menggunakan atau tidak menggunakan studi kasus sebagai strategi.

Dua diskursus keterbatasan metode dan pendekatan penelitian yang diuraikan di atas menjadi catatan penting dalam penelitian sosial dan budaya yang berupaya 
mengombinasikan seperangkat prinsip, cara pandang, dan ide (metodologi) dengan seperangkat praktis, teknis dan strategi yang spesifik (metode penyelidikan) untuk memproduksi ilmu pengetahuan (Neuman, 2007). Hal ini, terutama jika dihubungkan dengan debat metodologis yang menghendaki ketepatan penggunaan tiga komponen penting dalam penelitian, yaitu asumsi-asumsi pandangan dunia (worldview) filosofis yang dibawa ke dalam penelitian, strategi penelitian yang berhubungan dengan asumsiasumsi, dan metode atau prosedur-prosedur spesifik yang dapat menerjemahkan strategi ke praktek nyata (Creswell, 2010:6). Meskipun kedua keterbatasan telah mengemukakan masalah metodologis dan solusinya dalam penelitian sosial, baik Antropologi dengan pendekatan etnografinya maupun penelitian sosial secara umum dengan pendekatan studi kasus, terdapat pendekatan lain yang perlu dipertimbangkan penggunaannya dalam penelitian sosial. Pendekatan tersebut adalah Extended Case Method (ECM) yang oleh Rochman Achwan diterjemahkan ke dalam bahasa Indonesia sebagai studi kasus yang diperluas (Achwan, 2014).

Sebagai sebuah metode dalam penelitian kualitatif, ECM telah memiliki karakteristik sendiri. Karakteristik tersebut antara lain ditandai oleh pendekatan yang digunakan dalam proses penelitian sejak awal hingga akhir. Tulisan ini akan menguraikan beberapa hal yang bersifat spesifik pada ECM sebagai sebuah pendekatan dalam penelitian kualitatif. Pembahasan mencakup latar belakang, penggunaan teori dalam ECM, model-model perluasan dan kekuatan dan kelemahan ECM dalam penelitian sosial. Penjelasan ECM dalam artikel ini terutama akan mengacu pada Michael Buroway sebagai salah satu tokoh utama dan pengembang ECM dalam tradisi sosiologi.

\section{Metode}

Artikel ini merupakan telaah litetratur yang bertujuan untuk mendiskusikan ECM sebagai sebuah metode dalam penelitian sosial dan budaya. Sebagai telaah literatur, penulis menelusuri dan memeriksa berbagai tulisan yang berbeda yang telah mendiskusikan dan atau menerapkan ECM dalam penelitiannya (Gibson \& Brown, 2009, p. 36). Tulisan-tulisan Michael Buroway tentang ECM dijadikan sebagai rujuakn utama dalam penulisan artikel ini. Hal ini dilakukan untuk mendapatkan konsep dasar dan penerapan ECM dalam penelitian sosial budaya secara langsung dari penggagasnya. Selain tulisan-tulisan Buroway, artikel-artikel lain yang relevan dengan diskursus dalam pembahasan ECM juga digunakan dalam penulisan artikel ini. Penggunaan artikel lain bertujuan untuk mendapatkan pemahaman yang kritis terhadap konsep-konsep yang diperkenalkan oleh Buroway. Sehingga dengan demikian, penulisan artikel ini lebih komprehensif suntuk memahami ECM sebagai sebuah metode dalam penelitian sosial dan budaya.

\section{Hasil dan Pembahasan}

\section{- ECM Sebagai Studi Kasus Yang Diperluas}

Exetended Case Methode (ECM) yang diterjemahkan oleh Rochman Achwan ke dalam bahasa Indonesia sebagai studi kasus yang diperluas (Achwan, 2014) adalah pendekatan penelitian kualitatif yang muncul dari tradisi etnografi dalam disiplin Antropologi Sosial. ECM muncul pada mulanya dari British School of Anthropology (Tavory \& 
Timmermans, 2009) dimana saat itu tradisi ethnografi sangat dipengaruhi oleh strukturalisme Bronislaw Malinowski dan Radclife Brown (Gluckman, 1961). ECM diperkenalkan oleh Manchester School of Anthropology yang dipimpin oleh Max Gluckman pada tahun 1950-an untuk mempengaruhi teori fungsional-struktural yang sangat berpengaruh kala itu (Tavory \& Timmermans, 2009; Wadham \& Warren, 2014). Dalam menggunakan ECM, Antropolog Manchester menfokuskan perhatian mereka pada perilaku orang-orang, dimana perilaku tersebut bertentangan dengan apa yang seharusnya mereka lakukan. Fokus perhatian ini bertolak belakang dengan Antropolog tradisional yang pengamatan mereka fokus pada bagaimana masyarakat diorganisir melalui sistem, seperti kekerabatan dan agama (Wadham \& Warren, 2014).

Dalam disiplin Sosiologi, ECM dikembangkan oleh Buroway dengan fokus analisis yang kompleks dan bertingkat. Dengan prosedur yang bersifat induktif, ECM bertujuan untuk menempatkan suatu kasus tertentu ke lapangan sosial yang lebih luas dan relevan untuk memahami kasus tersebut (Sullivan, 2002). Burawoy mendefenisikan ECM sebagai:

...The extended case method applies reflexive science to ethnography in order to extract the general from the unique, to move from the "micro" to the "macro," and to connect the present to the past in anticipation of the future, all by building on preexisting theory (Burawoy, 1998, p. 5).

Defenisi yang diberikan oleh Burawoy mengacu pada pengalamannya sebagai konsultan industri tembaga di Zambia. Konsep ini kemudian banyak dikutip para ahli dalam menjelaskan dan menggunakan ECM sebagai metode penelitian ilmu sosial secara umum. Menurut penulis, defenisi yang diberikan oleh Burawoy ini mengacu pada apa yang sudah dilakukan oleh Sekolah Antropologi Manchester dalam menjelaskan dan menerapkan ECM sebagai sebuah metode. Dalam hal ini, ECM digunakan untuk memotret peristiwa-peristiwa kecil dalam keseharian masyarakat untuk menjelaskan gejala-gejala umum dan atau gejala-gejala makro yang terjadi. Oleh karenanya, ECM berangkat dari satu kasus sepesifik dan unik untuk menjelaskan gejala umum. Namun demikian, Burawoy dalam proyek penelitian Zambianisasinya, menyebutkan bahwa dia telah melakukan perluasan kasus yang ditelitinya dengan mengatakan "from the microworlds of Zambianization I "extended out" to the sources of underdevelopment" (Burawoy, 1998, p. 9).

Dengan melakukan perluasan pada kasus yang ditelitinya, Burawoy menempatkan ethnografi reflektif dalam ECM sebagai perekat yang menghubungkan oposisi konvensonal antara partisipan dan pengamat, mikro dan makro, sejarah dan sosiologi, tradisi teoritis dan penelitian empiris. Untuk menjembatani oposisi itu, Buroway menawarkan dialog guna mencarikan titik temunya. "Rather than arguing that there is one model of science that is best carried out with reflexive awareness, I propose a methodological duality, the coexistence and interdependence of two models of science-positive and reflexive" (Burawoy, 1998, p. 14). Ilmu-ilmu positif cenderung mengisolasi subjek dari objek, sebaliknya ilmu-ilmu refleksif menjadikan dialog sebagai prinsip penentu dan intersubjektifitas antara partisipan dan pengamat sebagai premisnya. Untuk itu, guna menjembatani dualisme ini, Buroway menerapkan prinsip 4R ilmu-ilmu positif (reactivity, reliability, replicability dan representativeness) pada ilmu-ilmu refleksif. 
Kemudian, prinsip-prinsip ilmu-ilmu refleksif (intervention, process, structuration, dan recontruction) diturunkan dari efek beberapa konteks yang menjadi penghalang bagi ilmu-ilmu positif. Penerapan prinsip-prinsip tersebut kemudian menghasilkan empat perluasan dalam penelitian studi kasus yang dikenal dengan ECM. Keempat perluasan tersebut dapat diuraikan sebagai berikut:

\section{- Perluasan Intervensi}

Dalam penelitian sosial, subjek-subjek penelitian tertentu terkadang merupakan peristiwa atau kasus yang sensitif di kalangan para aktor (Elam \& Fenton, 2003). Yang paling umum adalah tema-tema penelitian tentang konflik atau tema-tema penelitian yang bertentangan dengan aspek moral dan agama seperti prostitusi, perilaku menyimpang, aliran-aliran kepercayaan dan sebagainya. Untuk kasus-kasus yang seperti demikian, penting memperluas peran peneliti dari sebatas observer menjadi partisipan. Namun demikian, terdapat perdebatan antara pendekatan positifis dan refleksif dalam hal ini. Perspektif positifis berpandangan bahwa observasi partisipan akan menghasilkan pengetahuan mendalam melalui kedekatan, namun harus mengorbankan distorsi. Sebaliknya, perspektif refleksif menggunakan partisipasi justru karena sifatnya yang mendistorsi dan mengganggu itu (Burawoy, 1998, pp. 16-17). Untuk itu, pilihan menjadi partisipan adalah untuk tujuan intervensi terhadap situasi dimana penelitian dilakukan.

Dalam penelitiannya di Zambia, Burawoy memilih melakukan intervensi untuk merubah keadaan dengan menggunakan lagitimasi akademisnya. Dengan menerbitkan hasil penelitianya yang bertumpu pada data yang cermat, terperinci, dan dari dalam, Buroway mendorong proyek Zambianisasi yang lebih manusiawi dengan tanpa eksploitasi di sektor tambang. Publikasi yang dilakukan bertujuan untuk mengkritisi pemerintah, perusahaan dan ekspatriat yang eksplotatif. Di luar tujuan itu, manajer perusahaan tambang di Lusaka menggunakan publikasi ini sebagai acuan dalam mendisiplinkan manajemen perusahaan mereka.

Demikianlah perspektif refleksif, dimana peneliti perlu melakukan perluasan perannya dalam penelitian sebagai partisipan untuk melakukan intervensi terhadap keadaan tertentu. Jika dalam perspektif ilmu positif peneliti memiliki jarak dengan subjek penelitiannya dan terikat dengan seperangkat aturan dan instrument yang baku, maka dalam perspektif penelitian reflektif peneliti dapat saja menjadi bagian dari subjek yang ditelitinya dan memiliki fleksibilitas di lapangan untuk melakukan intervensi. Dalam proses keikutsertaannya dalam kasus yang sedang diteliti, observer bergabung dengan partisipan dalam ritme kehidupan mereka, dalam ruang dan waktu mereka. Observer bisa saja tetap berperan sebagai pengamat atau sebagai anggota partisipan. Terhadap perannya itu, observer boleh saja mendeklarasikan niatnya atau tetap menyamar (Burawoy, 2009).

\section{- Perluasan Proses}

Untuk melakukan proses yang lebih optimal, peneliti harus melakukan perluasan pengamatan dari ruang dan waktu tertentu ke ruang dan waktu lainnya agar tidak terjebak pada ruang dan waktu tertentu. Keterjebakan dalam ruang dan waktu tertentu meyebabkan peneliti hanya terfokus pada miniatur setiap hari yang memaksanya untuk 
meguji hipotesis yang selaras dengan teori yang digunakan. Sementara, gangguan dari luar menjadikan situasi menjadi lebih buruk untuk membangun dan membuktikan kerangka teoritik yang ada (Burawoy, 1998). Dalam hal ini, Buroway mengatakan bahwa tidak ada ketetapan yang mengatur berapa lama observer di lapangan, akan tetapi butuh waktu cukup lama untuk membedakan proses sosial yang berintegritas terhadap setting penelitian. Oleh karena itu, seorang etnografer terlibat dengan partisipan penelitan untuk waktu yang lama dan tempat yang berbeda. Mereka melakukan pencarian untuk memahami proses reprodusksi sosial melalui berbagai bentuk kegiatan seperti drama, ritual dan sebagainya yang berlangsung di lapangan (Burawoy, 2009).

Peneliti hanya akan mendapatkan pemahaman yang lebih komprehensif dan mendalam terhadap subjek penelitian dengan memperluas pengamatan dari waktu ke waktu. Untuk itu, Meyer dan Schareika (2009) berpandangan bahwa setiap observasi individu harus ditafsirkan dalam tiga proses, (a) apa yang terjadi sebelum dan sesudah observasi individu, (b) peristiwa yang mendahului dan mengikuti peristiwa yang dipelajari, dan (c) konteks di mana peristiwa itu terjadi (Schritt, 2019, p. 10). Perluasan proses ini dapat digunakan menjadi salah satu strategi untuk mempelajari masyarakat tanpa batas yang dibahas oleh Irwan Abdullah (2006) dan juga ambiguitas dalam studi kasus yang diuraikan oleh Verschuren (2003).

Dalam mempelajari masyarakat tanpa batas (borderless society) yang kehilangan batas geografis dan simbolik, perluasan ruang penelitian dari satu tempat ke tempat lainnya sangat memungkinkan untuk dapat memahami dinamika sosial suku bangsa di luar teritorial mereka. Memahami dinamika perkawinan antar desa, kecamatan, propinsi dan bahkan negara misalnya, akan sangat memungkinkan dengan tidak hanya melihat struktur sosial di satu tempat, akan tetapi melakukan perluasan dengan mengikuti migrasi budaya yang dibawa serta dalam perkawinan campuran tersebut. Hal yang sama, juga dapat dilakukan untuk mempelajari masyarakat yang melakukan migrasi dan membawa serta budaya mereka ke luar teritorial budayanya.

Perluasan proses dengan memperluas ruang dan waktu penelitian juga sangat memungkinkan untuk mengatasi keterbatasan studi kasus yang membatasi diri pada setting ruang dan waktu tertentu, sehingga terjebak ke dalam keterbatasan kedalaman analisis dan generalisasi. Meskipun melakukan perluasan terhadap ruang dan waktu penelitian, proses ini tidak sama dengan multiple case study dalam penelitian-penelitian yang mempertimbangkan banyak kasus untuk tujuan generalisasi (Battistella et al., 2017; Mora et al., 2019). Proses perluasan ruang dan waktu dalam ECM ditujukan untuk mendapatkan kedalaman dan keandalan informasi dengan mengikuti ruang-ruang sosial dimana kebudayaan berlangsung berdasarkan rangkaian waktu tertentu. Melalui proses ini, proses ekstraksi temuan pada kasus spesifik dapat digunakan untuk peristiwa yang umum sebagaimana kesimpulan Buroway bahwa hambatan terhadap pembangunan muncul tidak hanya dari ketergantungan pada tembaga dalam ekonomi dunia yang dikendalikan oleh negara-negara kapitalis maju, tetapi juga dari reproduksi hubungan kelas yang terus diwariskan dari kolonialisme. Hasil ekstraksi ini muncul dari pengamatan dari waktu ke waktu terhadap praktik yang terjadi di perusahaan tambang di Zambia. 
Namun demikian, dalam perluasan proses terdapat tiga hal yang mesti diperhatikan. Pertama, situasi sosial yang menjadi proses sosial karena tindakan sosial mengandaikan dan mereproduksi rezim tertentu. Kedua, dalam pergulatan di sekitar rezim, sejarah dan struktur makro disebut sebagai sumber daya dan skema dalam situasi sosial. Ketiga, intervensi dari luar situasi sosial memiliki konsekuensi yang terstruktur oleh rezim tertentu (Burawoy, 1998, p. 18). Tiga aspek yang saling berkaitan ini, terutama ketika peneliti telah memperluas peran mereka dari sebatas observer ke partisipan. Ketiga pertimbangan-pertimbangan ini perlu menjadi dasar bagi peneliti dalam mempertimbangkan perluasan tempat dan waktu dalam mempelajari situasi sosial tertentu.

\section{- Perluasan Strukturasi}

Dalam penelitiannya tentang Zambianisasi, Buroway memilih untuk tidak berhenti pada kesimpulan umum tentang color bar yang menjadi ruang perdebatan dalam struktur tenaga kerja di tambang timah. Buroway tidak berhenti pada kesimpulan umum bahwa bagaimanapun organisasi berubah, otoritas selalu mengalir dari pekerja kulit putih ke pekerja kulit hitam. Namun, Buroway memilih untuk melakukan perbandingan vertikal dengan menelusuri sumber-sumber perbedaan kecil pada kekuatan eksternal. Tujuannya adalah untuk menghubungkan antara kasus-kasus kecil dan menghubungkannya secara kausalitas, sehingga terlihat bahwa satu kasus fungsional terhadap kasus yang lain. Pendekatan ini disebut juga dengan pendekatan integratif atau vertikal (Burawoy, 1998, p. 19). Pendekatan ini kontras dengan teori dasar yang menerapkan perbandingan horizontal dengan mencari pola umum dalam berbagai kasus, atau dikenal dengan pendekatan segregatif atau horizontal (Burawoy, 1998; Schritt, 2019)

Dalam menganalisis Zambia, kekuatan internasional -yang oleh elit baru Afrika dianggap sebagai hambatan karena di luar kendali nasional- tidak hanya dilihat sebagai hambatan, namun juga sebagai sumber daya yang dimobilisasi elit untuk melegitimasi dominasinya. Oleh karena itu, bagi Buroway, reproduksi color bar di Zambia merupakan paradoks kepentingan kelas yang bertanggung jawab atas reproduksi tatanan rasial kolonial (Burawoy, 2014). Dalam pemahaman Buroway, kekuatan makro seperti kapitalisme global dan rasisme tidak hanya membatasi agensi aktor dalam situasi yang dipelajari, tetapi juga menyediakan sumber daya untuk digunakan para aktor. Namun demikian, dalam konseptualisasinya, kekuatan makro yang membentuk situasi dan akibatnya harus diberi fokus utama dalam analisis ECM (Schritt, 2019).

Berdasarkan formulasi ini, ECM berfokus terutama pada bagaimana struktur yang lebih besar mempengaruhi konteks situasional (Tavory \& Timmermans, 2009). Untuk memahami situasi sebagai inheren dalam struktur yang lebih besar, situasi makro dapat ditempatkan pada situasi lokal tertentu dan menghindari keharusan untuk menerima dan membayangkan hegemoni makro untuk melihat situasi lokal itu (Schritt, 2019). Dengan menjadikan struktur yang lebih besar (makro) sebagai kekuatan dibanding hambatan, Buroway telah berhasil memperluas prinsip strukturasi dengan menganggap pengaturan negara bagian dan kelas-kelas di Zambia sebagai proses terstruktur yang bersarang dalam konstelasi eksternal kekuatan-kekuatan internasional. Kemudian, menyimpulkan bahwa kekuatan internasional bukan sebagai hambatan, tetapi sebagai 
sumber daya yang dimobilisasi oleh elit penguasa untuk melegitimasi dominasinya (Burawoy, 2014).

\section{- Perluasan Teori}

Teori tidak hanya sebatas konsep definitif, atau definisi, atau isi realitas yang tepat, namun ia merupakan istilah yang disebut oleh Blumer (1954) sebagai "sensitizing concepts" (konsep yang peka). Dengan "konsep yang peka" peneliti dapat mendekati fenomena empiris dengan memberikan sugesti arah yang perlu dijadikan fokus perhatian. Agar fenomena empiris di lapangan dapat teramati dan tidak luput dari perhatian, konsep-konsep yang peka tersebut mesti disiapkan sebelum ke lapangan. Konsep-konsep itu disiapkan dari teori yang ada sebagai titik berangkat, bukan sebagai tujuan akhir. Selain itu, untuk menghindari fokus perhatian teralihkan ke aspek penting lainnya, penting bagi peneliti menghindari adopsi konsep atau teori yang didefinisikan terlalu sempit (Schritt, 2019).

Sebagai sebuah metode, ECM merupakan metodologi paradigmatik untuk mengembangkan teori sosial melalui etnografi (Glaeser, 2005). Oleh karena itu, perluasan teori merupakan tujuan akhir dan fondasi ECM. Hal inilah yang membedakan Buroway dengan tradisi Manchester yang berfokus pada peristiwa sebagai ilustrasi yang tepat untuk menjelaskan teori yang sudah ada ketimbang menghasilkan teori dan pemahaman baru. Sebaliknya, dalam ECM tujuan penelitian lapangan bukan untuk membuktikan teori, akan tetapi menolak suatu teori. Namun demikian butuh keberanin untuk meyakinkan diri bahwa apa yang ditemukan adalah benar, dan butuh keberanian untuk berimajinasi agar mampu menopang keberanian itu untuk merekonstruksi sebuah teori (Burawoy, 2009, p. 20). Dalam studinya tentang Zambianisasi, Buroway menolak teori yang menyebabkan ketebelakangan budaya yang digunakan dalam menjelaskan persoalan yang terjadi pada pekerja tambang di Zambia. Dengan menolak teori tersebut, kemudian ia mengambangkan teori post-kolonialnya Franz Fanon dengan mengatakan bahwa Zambia adalah sebuah koloni tanpa perjuangan pembebasan nasional berbasis petani. Analisisnya terhadap perusahaan multinasional, pekerja tambang, manajer Zambia, dan ekspatriat paralel dengan pembedahan tentang kepentingan kelas kaum borjuis nasional, intelektual, dan kaum tani (Burawoy, 1998).

\section{- Kekuatan dan Kelemahan ECM}

Sebagai sebuah metode, sebagaimana metode-metode yang lain yang tidak lepas dari kelebihan dan kekurangan, ECM juga seperti demikian. Buroway telah mengatakan bahwa pada ECM terdapat empat kekuatan dan juga tantangan yang dihadapi. Kekuatan ECM itu adalah pada intervensi, proses, strukturasi dan rekonstruksi yang diterapkan dalam perluasan penelitian. Intervensi mengacu pada perluasan peran peneliti dari observer menjadi partisipan, proses mengacu pada perluasan ruang dan waktu penelitian, strukturasi mengacu pada proses menjadikan proses sosial menjadi kekuatan sosial dan rekonstruksi mengacu pada perluasan teori. Studi Buroway tentang Zambianisasi yang dijadikan contoh dalam penulisan ECM adalah studi dimana dia mengembangkan keempat aspek tersebut. Dalam kasus yang diteliti, sebagai peneliti Buroway ikut serta dalam proyek sebagai konsultan industri timah. Penelitian Zambianisasi diperluas oleh Buroway ke kontek kolonialisme negara-negara kapitalis 
dunia. Kemudian, hasil studi dijadikan oleh Buroway sebagai bagian dari advokasi atas hak-hak buruh. Dan terakhir, Buroway mengkritik teori kolonialisme klasik melalui temuan-temuanya.

Selain kekuatan, juga terdapat kelemahan yang merupakan efek dari kekuatan ECM dalam proses perluasan. Kelemahan tersebut juga diindetifikasi Buroway dari kasus study Zambianisasinya, dan kemudian dia sebut sebagai ancaman. Ancaman tersebut adalah domination, silencing, objektification dan normalization. Keempat ancaman tersebut merupakan efek dari kekuatan ECM (lihat tabel. 1). Pertama dominasi. Buroway mengatakan bahwa peneliti atau ilmuan sosial tidak bisa lepas dari dominasi, baik didominasi ataupun mendomasi. Ancamannya adalah, dalam proses penelitian intervensi peneliti terhadap subjek penelitiannya dengan menjaddi partisipan akan menjadikan dominasi peneliti terhadap subjek, sehingga peneliti akan cenderung subjektif dalam proses peneltian. Selain itu, peneliti juga bisa saja didominasi oleh kekuatan di luar dirinya yang akan mengarahkannya dalam proses penelitian. Sehingga, kekuatan peneliti sebagai bagian dari subjek yang diteliti adalah penting dalam proses intervensi. Kedua, pembungkaman. Peneliti akan terus mendapatkan tekanan dari teoriteori yang dikembangkan dalam proses pembentukan kolonilaisme baik oleh negara atau perusahaan. Pembungkaman itu bisa saja dalam bentuk pembatasan ruang gerak peneliti dengan membatasi sumber daya dan akses terhadap subjek penelitian. Sehingga, peneliti tidak dapat melakukan perluasan tempat dan durasi penelitiannya. Hal ini akan berimplikasi terhadap upaya peneliti dalam memperluas area dan waktu studi yang dilakukan.

Ketiga, objektifikasi. Buroway mengatakan bahwa objektifikasi lebih dari sebatas alat metodologi, dia juga sekaligus merefleksikan kekuatan ril yang dilakukan oleh sistem politik, ekonomi dan sistem kebudayaan. Tantangan itu ada pada upaya mengobjektifikasi si peneliti terhadap upaya-upaya mengentalkan gerakan sosial dari hasil penelitiannya. Seperti dalam studi Zambianisasinya, tampaknya Buroway kesulitan untuk tidak menjadi bagian dari suara pekerja buruh di tambang timah dan menyuarakannya ke arah perubahan aturan. Keempat, normalisasi. Dalam poses ini, tantangan sesungguhnya adalah keberanian dalam menentang, membangun dan mengembangkan teori yang ada. Dibutuhkan kekuatan teoritik dan keberanian untuk merekonstruksi teori.

Tabel 1. Penerapan Prinsip Reflexive Science Pada ECM

\begin{tabular}{lll}
\hline Reflexive Principles & Extended Case Methode & Power Effect \\
\hline Intervention & $\begin{array}{l}\text { Extension of observer to the } \\
\text { participant }\end{array}$ & Domination \\
Process & $\begin{array}{l}\text { Extension of observations over } \\
\text { time and space }\end{array}$ & Silencing \\
Structuration & $\begin{array}{l}\text { Extension from process to force } \\
\text { Reconstruction }\end{array}$ & $\begin{array}{l}\text { Objectification } \\
\text { Extension of theory }\end{array}$ \\
\hline
\end{tabular}

Sumber : Buroway, 1998.

Di luar apa yang disampaikan oleh Buroway, Wadham dan Warren (2014) mengingatkan bahwa ECM memiliki tiga bahaya bagi pengguna yang tidak hati-hati dalam menggunakannya. Ketiga bahaya tersebut adalah, menentukan apa yang berarti/signifikan dan apa yang penting dalam proses penelitian, terlalu mementingkan 
temuan teoritis yang dihasilkan dari penelitian, dan terlalu tinggi menilai sifat kolaboratif dan dialogis dalam proses penelitian. Ketiga bahaya tersebut tentu saja akan muncul bagi peneliti yang terlalu sempit dalam memahami ECM sebagai sebuah metode dan tidak hati-hati dalam menggunakannya untuk sebuah penelitian sosial.

Ketiga ancaman yang diidentifikasi oleh Wadham dan Warren dapat diterapkan baik pada penggunaan teori maupun pada proses perluasan. Tiga proses awal dalam perluasan yang dsebut oleh Buroway dengan tahapan intervensi, proses dan strukturasi akan menjadikan peneliti terlibat jauh dengan penelitiannya dan akan dapat menggiring peneliti menjadi subjektif dalam melihat penelitian yang dilakukannya. Subjektifitas ini yang kemudian menjadikan peneliti menilai terlalu ideal terhadap kolaborasi dan dialog, sehingga kesulitan dalam membedakan yang berarti dan yang penting. Pada proses perluasan teori atau diisitilahkan Buroway dengan rekontruksi yang menjadi tujuan utama penelitian ECM, peneliti akan cenderung terjebak dalam menghasilkan dan atau menemukan teori baru jika hanya berfokus pada pemahaman bahwa ECM adalah untuk melahirkan teori baru.

Terlepas dari apa yang disebutkan oleh Wadham dan Warren, menurut penulis terdapat kekuatan dan kelemahan pada penggunaan teori dan proses perluasan penelitian dalam penggunaan ECM sebagai pendekatan penelitian. Kekuatan dan kelemahan tersebut adalah, pertama pada penggunaan teori. Seperti akan diuraikan setelah ini, penggunaan teori dalam penelitian adalah sebagai pembimbing peneliti sejak awal penelitian hingga akhir. Dalam artian seluruh tahapan penelitian dengan menggunakan ECM tidak lepas dari keterlibatan teori sebagai acuan. Hal ini menurut penulis merupakan kekuatan sekaligus kelemahan. Kekuatannya adalah, peneliti bisa menjadi terarah dan fokus terhadap penelitiannya karena dibimbing dengan baik oleh teori. Di sisi lain, keterlekatan teori terhadap penelitian ini adalah sekaligus kelemahan. Dengan mengacu pada teori tertentu, peneliti tidak dapat keluar dari tuntunan teori selama proses penelitian. Peneliti baru bisa membantah, mempebarui dan merekonstruksi teori setelah melakukan penelitian. Selama penelitian, peneliti harus patuh pada tuntunan teori yang digunakan. Hal ini berbeda dengan pendekatan yang tidak mengutamakan teori seperti grounded yang bisa saja menemukan dan mengembangkan teori selama porses penelitian berlangsung.

\section{- Penggunaan Teori dalam ECM}

Untuk menjelaskan penggunaan teori dalam ECM, adalah menarik menyimak introduksi Burawoy dalam menjelaskan ECM pada artikelnya dengan judul yang sama. Burawoy memulai tulisannya dengan menawarkan dua cara dalam menutupi kelemahan dalam pendekatan etnografi. Dua cara tersebut adalah dengan memilih salah satu dari dua cara, yaitu membatasinya atau mengembangkannya menjadi lebih bermanfaat. Menggunakan cara pertama adalah sama dengan menggunakan pendekatan postivistik, yaitu menggunakan seperangkat instrumen dengan aturan yang baku untuk memahami masyarakat dimana peneliti menjaga jarak dengan subjek penelitiannya. Cara kedua adalah cara yang disebut Buroway dengan reflexive science, dimana penelitian menafsirkan keterlibatannya dengan dunia yang diteliti dengan tetap bersandar pada teori yang akan memandunya berdialog dengan partisipan. 
Sebagaimana positive science adalah untuk penelitian survei, maka reflexive science adalah untuk ECM (Burawoy, 1998).

Tavory dan Timmermens mengatakan bahwa dalam ECM seorang peneliti menggunakan teori sebagai titik awal memahami suatu kasus yang menjadi subjek penelitian (Tavory \& Timmermans, 2009). Penggunaan teori dalam ECM adalah untuk membingkai kasus yang diteliti sejak awal penelitian dilakukan hingga akhir. "We begin with our favorite theory" kata Buroway, tapi bukan untuk mengonfirmasi apakah teori itu benar atau salah, melainkan untuk menyanggahnya agar mendapatkan inspirasi untuk mendalaminya. Oleh karena itu, titik tolak ECM adalah utnuk mengelaborasi teori yang sudah ada (Burawoy, 1998). Dengan menjadikan teori sebagai pemandu dalam penelitian, maka ECM memproduksi produk etnografi yang dibangun secara teoritis, atau apa yang disebut dengan istilah "theorygraphy", dimana kegiatan penelitin bertujuan untuk memodifikasi, memberi contoh, dan mengembangkan teori yang ada (Tavory \& Timmermans, 2009) dengan tujuan akhir merekonstruksi teori (Wadham \& Warren, 2014).

Secara teknis, penggunaan teori dalam penelitian sosial dengan menggunakan ECM dapat dibaca pada tulisan Rochman Achwan (2014) dalam memahami industri kreatif fesyen di Bandung dan Bali. Dalam menjelaskan industri kreatif di dua lokasi ini, Achwan memulai mendekatinya dengan sosiologi seni dan sosiologi ekonomi. Kedua sub kajian sosiologi ini dijadikan sebagai pintu masuk untuk meletakkan pendekatan sosiologi dalam memahami subjek penelitian. Dengan menggunakan dua sub didipilin sosiologi ini, penulis kemudian menjelaskan aktor (agency) yang berperan dalam industri ini, baik sebagai kegiatan seni maupun sebagai kegiatan ekonomi. Teori jaringan digunakan oleh penulis untuk menjelaskan aktor. Teori jaringan yang digunakan oleh penulis adalah teori jaringan kelembagaan yang diperkenalkan oleh Peter Evans dan Fred Block (2005) yang menfokuskan pada hubungan antar makro institusi seperti politik, ekonomi dan masyarakat (Achwan, 2014). Teori sudah digunakan oleh peneliti sejak menyusun rancangan penelitian di bagain pendahuluan/latar belakang untuk memandunya dalam melakukan penelitian.

Secara metodologis, Achwan menjelaskan pendekatan yang digunakan dalam penelitian, yaitu ECM. Achwan merincikan dua tahapan dalam proses pelaksanaan penelitiannya, yaitu tahap studi literatur dan data sekunder (desk study) dan tahap pengumpulan data lapangan melalui wawancara (Achwan, 2014). Menurut kami, tahap penting penggunaan teori dalam ECM yang dilakukan Achwan adalah tahap pertama, yaitu studi literatur. Dalam hal ini, Achwan berupaya menemukan konsep yang akan membimbingnya di lapangan agar penelitian yang dilakukan mencapai sasaran. Sejak semula, penelitian sudah dibingkai dengan teori yang akan digunakan. Lalu, di lapangan peneliti mengambil kasus yang spesifik (ditentukan) untuk dipelajari dalam upaya memahami konteks yang lebih luas, yaitu jaringan kelembagaan. Kasus industri fesyen di Bandung dan Bali dipilih untuk menjelaskan jaringan kelembagaan dalam sosiologi seni dan sosiologi ekonomi.

Dalam penyajian data lapangan, Achwan menguraikan temuannya sesuai dengan kerangka teoritik jaringan kelembagaan. Dalam menceritakan aktor yang bermain dalam arena insdustri fesyen, deskripsi data berfokus pada aktor-aktor dalam kerangka 
jaringan kelembagaan. Maka, data yang disajikan dalam laporan penelitian tidak keluar dari upaya menjelaskan aktor yang melekat dengan lembaga yang ada, baik lembaga formal maupun lembaga informal. Dalam interpretasi data dan menarik kesimpulan, Achwan masih dalam kerangka teori jaringan kelembagaan dengan menginterpretasi bagaimana jaringan kelembagaan yang ada dalam arena fesyen berhubungan untuk kepentingan seni dan atau ekonomi. Dan terakhir, Achwan mengemukakan bahwa tidak cukup hanya jaringan kelembagaan yang ada saja dalam mengembangkan kapasitas industri fesyen di dua kota yang menjadi objek studinya. Berdasarkan itu dia berargumen ada faktor lain yang juga sangat diperlukan dalam pengembangan kapasitas itu, dan keberadanya di luar wilayah jaringan sosial yang ada. Faktor tersebut dicontohkan seperti kepemimpinan dalam lembaga dan adanya anggota jaringan yang mampu mengakses organisasi di luar wilayahnya sendiri. Dari argumen ini Akhwan menawarkan konsep di luar teori yang sudah digunakan sejak awal, yaitu structural hole atau agency dalam sosiologi ekonomi. Apa yang dilakukan Achwan ini adalah upaya yang dilakukan oleh peneliti dalam mengembangkan teori dalam pendekatan ECM.

Mengacu pada konsep ECM dan contoh penelitian dengan menggunakan pendekatan ECM di atas, dapat dipahami bahwa penggunaan teori dalam ECM adalah pada keseluruhan rangkaian dan tahapan penelitian. Dalam hal ini, teori sudah dikonstruksi sejak merumuskan masalah penelitian, menentukan kasus yang akan diteliti, menentukan metode dan teknik pengumpulan data, menyajikan data lapangan dan terakhir analisis data lapangan. Maka, penulis mencoba untuk menggambarkan proses penggunaan teori dalam penelitian ECM dalam skema yang penulis bangun dari bahan yang ada. Skema tersebut adalah sebagai berikut:

Skema penggunaan teori dalam penelitian ECM

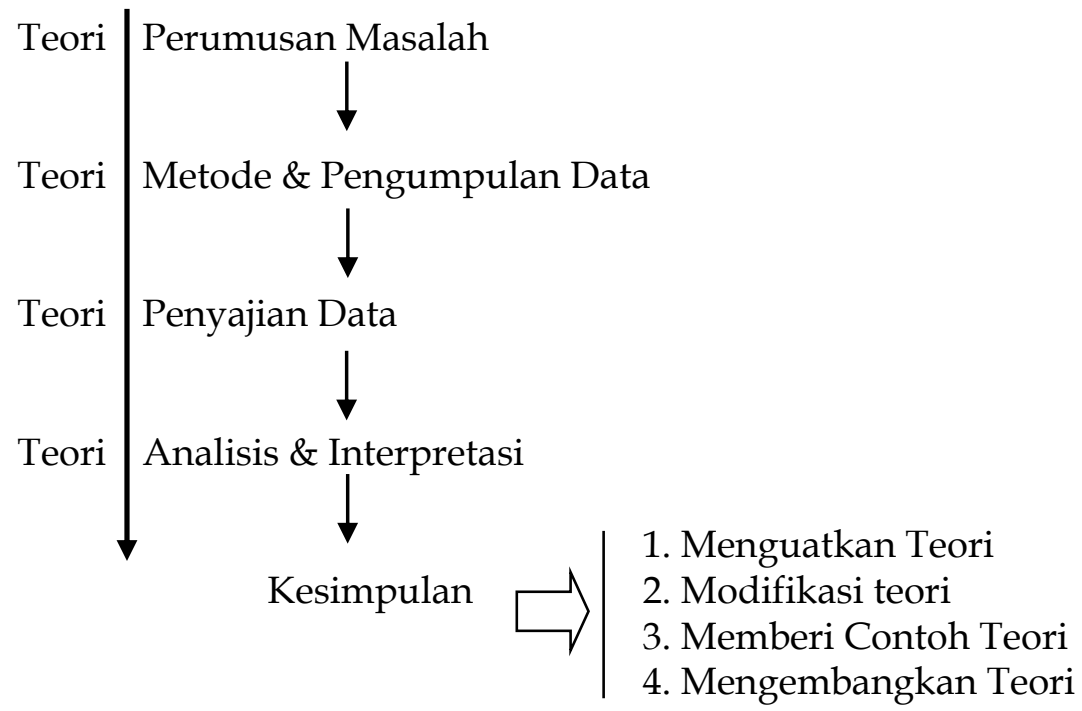

Sumber: Diekstrak dari bahan bacaan

Dengan skema ini, maka dapat dipahami apa yang dikatakan oleh Buroway bahwa teori membimbing peneliti setiap hari. Teorilah yang akan menyarankan hipotesis apa yang didalami dan anomali-anomali yang akan dihentikan (Burawoy, 2009). Maka seluruh 
tahapan dalam proses penelitian ECM tidak lepas dari teori sebagai bingkainya, lalu pada akhirnya peneliti melakukan pengembangan terhadap teori tersebut atau justru sebaliknya, membantah taori yang ada dengan reason dan evidence yang baru.

\section{Kesimpulan}

ECM merupakan pengembangan dari pendekatan etnografi dalam tradisi Antropologi. Dikembangkan oleh Antropologi Sosial Inggris pda tahun 1950-an, ECM berkembang dalam tradisi sosiologi di tangan Buroway. Dalam pengembangannya, Buroway mencoba memperlakukan pendekatan penelitian positif -pendekatan survei- ke penelitian reflexife -extended case method. Hasilnya, Buroway memperkenalkan empat prinsip dalam penelitian reflektif, yaitu intervensi, proses, strukturasi dan rekonstruksi yang sekaligus adalah kekuatan ECM. Masing-masing memiliki pendekatan sendiri dalam proses perluasan, yaitu perluasan peran peneliti dari observer menjadi partisipan, perluasan ruang dan waktu untuk pengamatan, perluasan dari proses ke kekuatan, dan perluasan teori. Selain itu, penggunaan ECM sebagai pendekatan penelitian sosial kualitatif, sejak awak sudah dibingkai dengan teori yang digunakan dalam penelitian.

Meskipun sudah berkembang relatif lama, di Indonesia ECM tampaknya belum begitu populer dan belum banyak digunakan dalam penelitian sosial. Penulis sendiri tidak banyak menemukan hasil penelitian di Indonesia yang menggunakan ECM sebagai metode. Padahal, untuk penelitian-penelitian sosial Indonesia, banyak masalah penelitian yang diambil dari masalah sosial. Hal ini, tidak lain karena status sebagai negara berkembang yang belum mapan dalam menyelesaikan masalah-msalah sosial yang ada berbasis penelitian. Sehingga dengan mengacu pada apa yang sudah didedahkan di atas, ECM akan dapat menjadi alternatif dalam metode penelitian sosial di Indonesia, terutama penelitian yang diorientasikan untuk merubah kebijakan yang ada, atau minimal mempengaruhi kebijakan.

\section{Ucapan Terima Kasih}

Penulis mengucapkan terima kasih yang sebesar-besarnya kepada Prof. Rochman Achwan (Guru Besar Sosiologi UI) yang pertama kali memperkenalkan Extended Case Method (ECM) kepada kami. Untuk keperluan publikasi ini, kami melakukan penggalian lebih lanjut melalui penelusuran terhadap ECM sebagai sebuah metode dalam penelitian sosial dan budaya yang dianggap penting untuk menghantarkan pembaca dalam memahami dasar-dasar ECM.

\section{Conflicts of Interest}

Penulis menyatakan tidak ada konflik kepentingan dalam penulisan artikel ini.

\section{Daftar Pustaka}

Abdullah, I. (2006). Dari Bounded System ke Borderless Society: Krisis Metode Antropologi dalam Memahami Masyarakat Masa Kini. Jurnal Antropologi Indonesia, 30(2), 185-192.

Achwan, R. (2014). Dua Dunia Seni : Industri Kreatif Fesyen di Bandung dan Bali. Jurnal Sosiologi Masyarakat, 19(1), 57-75. 
Battistella, C., De Toni, A. F., De Zan, G., \& Pessot, E. (2017). Cultivating business model agility through focused capabilities: A multiple case study. Journal of Business Research, 73, 65-82. https://doi.org/10.1016/j.jbusres.2016.12.007

Burawoy, M. (1998). The Extended Case Method. Sociological Theory, 16(1), 1-33.

Burawoy, M. (2009). The Extended Case Method: Four Countries, Four Decades, Four Great Transformations, and One Theoretical Tradition. University of California Press.

Burawoy, M. (2014). The Colour of Class Revisited: Four Decades of Postcolonialism in Zambia. Journal of Southern African Studies, 40(5), 961-979. https:/ / doi.org/10.1080/03057070.2014.946213

Creswell, J. W. (2010). Research Design; Pendekatan Kualitatif, Kuantitatif dan Mixed. Pustaka Pelajar.

Elam, G., \& Fenton, K. A. (2003). Researching sensitive issues and ethnicity: Lessons from sexual health. Ethnicity and Health, 8(1), 15-27. https://doi.org/10.1080/13557850303557

Geertz, C. (1973). Interpretation of Cultures. Basic Books.

Geertz, C. (1981). Abangan, Santri dan Priyayi. Pustaka Jaya.

Geertz, C. (1992). Tafsir Kebudayaan. Kanisius.

Geertz, C. (1998). After the Fact: Dua Negeri, Empat Dasawarsa, satu Antropolog. LKIS.

Gibson, W. J., \& Brown, A. (2009). Working with Qualitative Data. SAGE Publications Ltd.

Glaeser, A. (2005). An Ontologi for the Ethnographic Analysis of Social Processes: Extending the Extended-Case Method. Social Analysis, 49(3), 16-45.

Gluckman, M. (1961). Ethnographic data in british social anthropology. The Sociological Review, 9(1), 5-17. https://doi.org/10.1111/j.1467-954X.1961.tb01082.x/abstract

Mora, L., Deakin, M., \& Reid, A. (2019). Strategic principles for smart city development: A multiple case study analysis of European best practices. Technological Forecasting and Social Change, 142, 70-97. https:// doi.org/10.1016/j.techfore.2018.07.035

Neuman, W. L. (2007). Basic of Social Research; Qualitatif and Quantitatif Approach. Pearson Education, Inc.

Schritt, J. (2019). An ethnography of public events: Reformulating the extended case method in contemporary social theory. Ethnography. https://doi.org/10.1177/1466138119891446

Sullivan, M. L. (2002). Exploring Layers; Extended Case Method as a Tool for Multilevel Analysis of School Violence. Sociological Methods E Research, 31(2), 255285. https:/ / doi.org/10.1177/004912402237295

Tavory, I., \& Timmermans, S. (2009). Two cases of ethnography: Grounded theory and the extended case method. Ethnography, 10(3), 243-263.

https://doi.org/10.1177/1466138109339042

Verschuren, P. (2003). Case study as A Research Strategy: Some Ambiguities and Opportunities. International Journal of Social Research Methodology, 6(5), 12-139. https://doi.org/10.1080/13645570110106154

Wadham, H., \& Warren, R. C. (2014). Telling Organizational Tales: The Extended Case Method in Practice. Organizational Research Methods, 17(1), 5-22. 
ETNOSIA: Jurnal Etnografi Indonesia 6(1): Extended Case Method https:/ / doi.org/10.1177/1094428113513619

Yin, R. K. (2003). Case Study Research; Design and Methods (Third Edit). Sage Publication Ltd. 